\title{
Spatial Temporal Analysis of Coral Reefs in Belitung Tourism Destination Islands
}

\author{
Pavita Raudina Sari ${ }^{1}$, Ratna Saraswati ${ }^{1, *}$, and Adi Wibowo ${ }^{1}$ \\ ${ }^{1}$ Department of Geography, Faculty of Mathematics and Natural Sciences, Universitas Indonesia, Depok - Indonesia
}

\begin{abstract}
One of the world's most spectacular ecosystems in this world is the coral reef. In Indonesia, Bangka Belitung is one province which has beautiful coral reefs and has become one of the tourist attractions. However, there might be a loss of the coral reefs area that can be caused by natural factors and human activities. This study aims to analyze the distribution and the changing of coral reefs that occurred in the islands of tourist destination in Belitung Regency from 2005 to 2018 and to analyze its factors. Landsat satellite imageries used in this study are Landsat 5 TM, Landsat 7 ETM+, and Landsat 8 OLI/TIRS. The distribution of coral reefs will be determined by image data processing. Then, overlay methods are used to analyze the changes and its factors. Based on the analysis, in the year of $2005-2018$, there are $3.93 \mathrm{~km}^{2}$ areas of coral reefs that have decreased. On the top of that, there are $1.34 \mathrm{~km}^{2}$ or about $34.04 \%$ of coral reefs areas have decreased that caused by non-natural factors. It can be concluded that the decreased of the coral reefs occurred in Belitung tourism destination islands, are still dominated by natural factors rather than a nonnatural factor.
\end{abstract}

Keywords: Belitung Regency; Coral Reefs; GIS; Multi-Temporal Landsat; Remote Sensing.

\section{Introduction}

One of the world's most spectacular ecosystems in the world is the coral reef lived in shallow-water [1]. In Southeast Asia, the most extensive coral reefs area is located in Indonesia with $17,500 \mathrm{~km}^{2}$ to $85,707 \mathrm{~km}^{2}$ depends on the scientists' various criteria [2]. In Indonesia, among others, there is one province which has beautiful coral reefs and has become one of the tourist attractions that very accessible in Bangka Belitung Province. According to the maps of coral reefs by Bakosurtanal, the extent of coral reefs in Bangka Belitung reach 29,662.11 ha and spread in 6 districts [3]. In Bangka Belitung Province, the regency which has the most extensive coral reefs is Belitung Regency with 14,750.43 ha [3]. As the regency with the most extensive coral reefs in Bangka Belitung Islands, making Belitung as a tourist attraction for snorkeling and diving that located in an area near Lengkuas Island.

The estimates of the coral reefs worldwide by the Global Coral Reef Monitoring Network (GCRMN) supported by the professional opinions of 372 coral reef scientists and managers from ninety six countries recommend that this planet has lost 19\% of the coral reefs, $15 \%$ seriously vulnerable with loss inside the subsequent 10-20 years and an extra 20\% area below threat of loss in 20-40 years [4]. A study by United Nations Educational
Scientific and Cultural Organization disclosed that tourists skin diving on coral reef in southern African exceeded 10.000 dives annually and such levels of use are unsustainable due to inevitable accidental harm to reefs [5]. Thus, this research aims to analyze the distribution, the changing of coral reefs that occurred in the islands of tourist destination in Belitung Regency from 2005 to 2018 and to analyze its factors. By knowing the changing of the coral reefs, then efforts can be identified to control the decrease of the coral reefs, which is associated with low carbon development.

\section{Methodology}

The study area of this research is parts of seawater that exist in Belitung Tourism Destination in Belitung Regency. The coordinates of this area are from $107^{\circ} 08^{\circ} \mathrm{E}$ to $107^{\circ} 58^{\prime} \mathrm{E}$ and from $02^{\circ} 30$ 'S until $03^{\circ} 15^{\prime} \mathrm{S}$ with a total area of 229,369 ha or about 2,293.69 $\mathrm{km}^{2}$. Belitung regency has boundaries with the South China Sea in the north, with East Belitung Regency in the east, with the Java Sea in the south, and the Gaspar Strait in the west. Belitung Tourism Destination consists of several islands that frequently visited by tourists such as Batu Garuda Island, Pasir Island, Batu Berlayar Island, Lengkuas Island, Burung Island, Kepayang Island, and Kelayang Island.

* Corresponding author: ratna.saraswati@ui.ac.id 
In the study area, satellite imageries such as Landsat 5 TM for 2005, Landsat 7 ETM+ for 2011, and Landsat 8 OLI for 2018 are used and taken from the United States Geological Survey (USGS) of path 122 and row 62 . Satellite imageries that have been corrected, calibrated, and classified into undersea objects such as coral reefs, sand, and sea. There are one algorithm which is used to identify all of them. Lyzenga's water column correction algorithm is used to identify coral reefs. The best option to be applied in the area with a lack of water optical data is Lyzenga's method [6]. The composite images that used for lyzenga's algorithm are 3-2-1 for Landsat 5 TM and Landsat 7 ETM+, and 4-3-2 for Landsat 8 OLI. To analyze the changes in the coral reefs area used the overlay method. Then, for non-natural factors such as snorkeling spot buffered as far as 200 meters and the cruise line buffered as far as 100 meters.

\section{Result and Discussion}

\subsection{Coral Reefs in Belitung Tourism Destination Islands in 2005-2018}

The result of the classification illustrate that the sea dominates Belitung Tourism Destination of $69.45 \%$. The mainland and other islands have only $18.59 \%$ percentage, while $5.01 \%$ consists of sand. The coral reefs have various percentages. In 2005, the area of coral reefs is up to 5.05 $\mathrm{km}^{2}$. In 2001 the area of coral reefs is $1.98 \mathrm{~km}^{2}$. The area of coral reefs had area of $1.39 \mathrm{~km}^{2}$ in 2018 . The area each class presented on Table 1 and the distribution of coral reefs each year presented in the map of coral reefs in Belitung Tourism Destination (see Figure 1, Figure 2, and Figure 3).

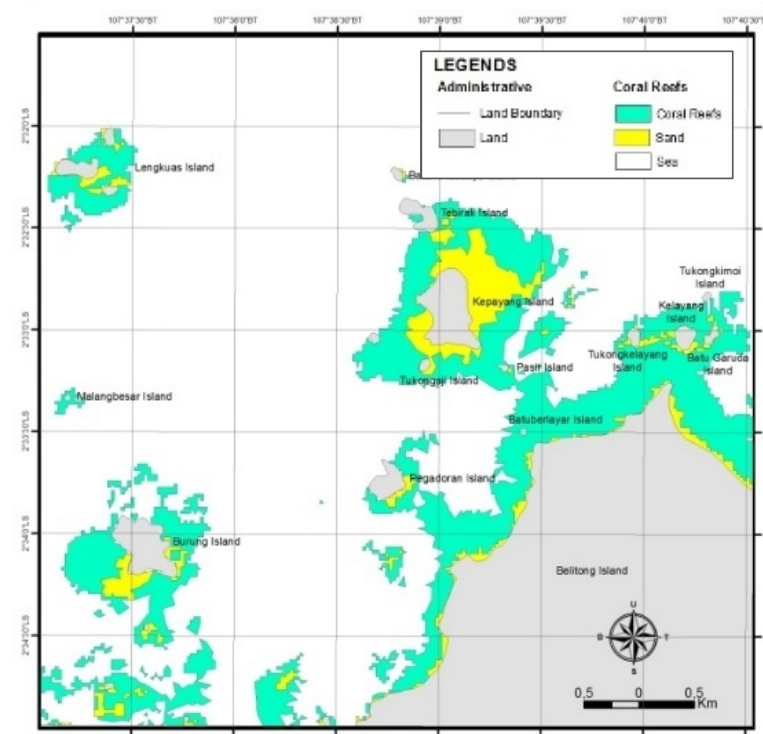

Fig. 1. Map of Coral Reefs on study area in 2005.

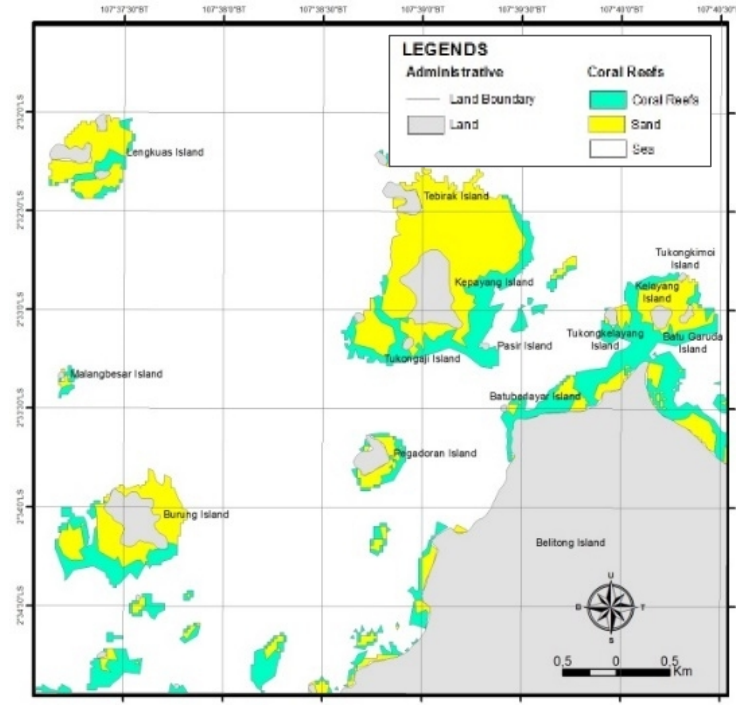

Fig. 2. Map of Coral Reefs on study area in 2011.

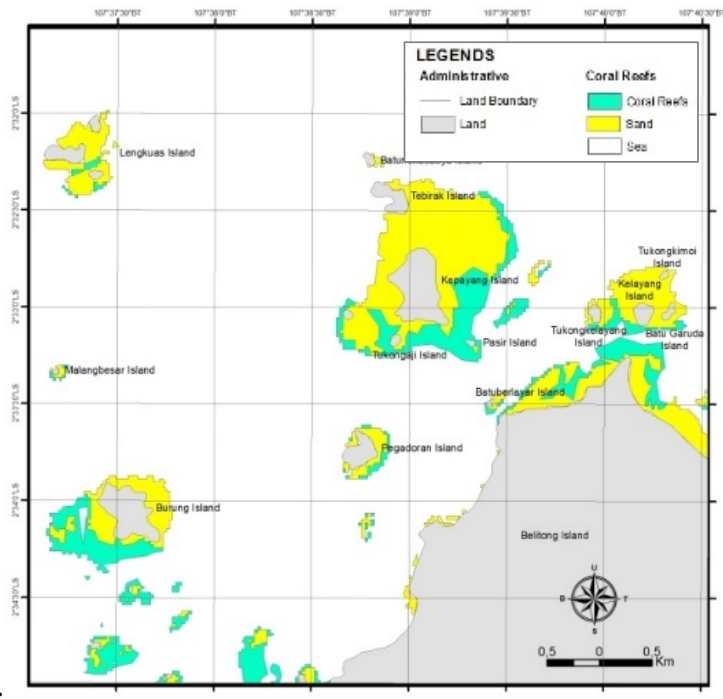

Fig. 3. Map of Coral Reefs on study area in 2018.

Table 1. Coral Reefs Area in Belitung in 2005-2018.

\begin{tabular}{|c|c|c|c|c|c|c|c|}
\hline No. & Class & \multicolumn{2}{|c|}{2005} & \multicolumn{2}{|c|}{2011} & \multicolumn{2}{|c|}{2018} \\
$\left(\mathrm{Km}^{2}\right)$ & Percentage & $\begin{array}{c}\text { Area } \\
\left(\mathrm{Km}^{2}\right)\end{array}$ & Percentage & $\begin{array}{c}\text { Area } \\
\left(\mathrm{Km}^{2}\right)\end{array}$ & Percentage \\
\hline 1 & $\begin{array}{c}\text { Coral } \\
\text { Reefs }\end{array}$ & 5.05 & 12.49 & 1.98 & 4.91 & 1.39 & 3.43 \\
\hline 2 & Sand & 1.00 & 2.48 & 2.52 & 6.24 & 2.56 & 6.32 \\
\hline 3 & Land & 7.52 & 18.59 & 7.52 & 18.59 & 7.52 & 18.59 \\
\hline 4 & Sea & 26.87 & 66,44 & 28.42 & 70.27 & 28.98 & 71.65 \\
\hline & Total & 40.44 & 100 & 40.44 & 100 & 40.44 & 100 \\
\hline
\end{tabular}

Sources: Data Processing and Analysis

\subsection{Coral Reefs Changing in Belitung Tourism Destination Islands in 2005-2018}

Based on the overlay analysis, in the year of 2005 and 2011, the area of coral reefs has changed around 3.07 $\mathrm{km}^{2}$ or $60.72 \%$. While in 2011 and 2018, the area of coral reefs has changed around $0.60 \mathrm{~km}^{2}$ or $30.06 \%$. In 2005 2011 , there was an increased and decreased of the coral 
reefs area dominated by the area that decreased. There was $3.60 \mathrm{~km}^{2}$ of coral reefs area that decreased, $1.45 \mathrm{~km}^{2}$ of coral reefs that unchanged, and $0.33 \mathrm{~km}^{2}$ of coral reefs that increased. The decreased area mostly occurred in the north of Kepayang Island, in the southeast of Belitung Island, and around Lengkuas Island. In 2011-2018, there was an increased and decreased of the coral reefs area dominated by the area that decreased. There was $1.08 \mathrm{~km}^{2}$ of coral reefs area that decreased, $0.90 \mathrm{~km}^{2}$ of coral reefs area unchanged, and $0.49 \mathrm{~km}^{2}$ of coral reefs that increased. The decreased area occurred in the north of Kelayang Island and Batu Garuda Island. It inferred that there is a slow-down in the decreasing of the coral reefs that see in Table 2. In 2005-2018, the total decreased area of the coral reefs occurs as much as $3.93 \mathrm{~km}^{2}$, the increased area of the coral reefs is $0.27 \mathrm{~km}^{2}$, and $1.12 \mathrm{~km}^{2}$ of coral reefs is unchanged. The decreased area of the coral reefs occurs in the north of Kepayang Island, southeast of Belitung Island, around Burung Island, around Batu Garuda Island and Kelayang Island, and around Lengkuas Island (see Figure 4, Figure 5, and Figure 6).

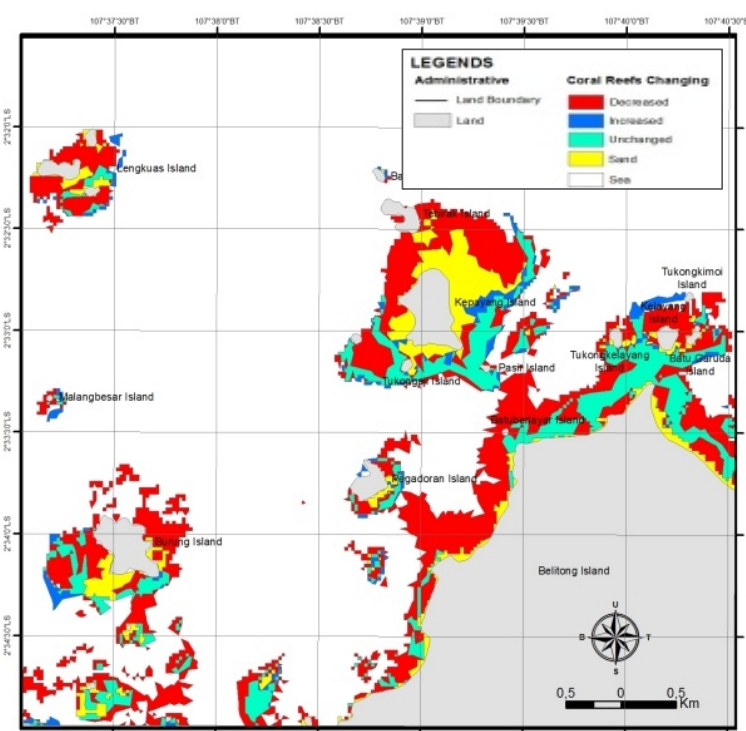

Fig. 4. Map of Coral Reefs Changing in 2005 and 2011.

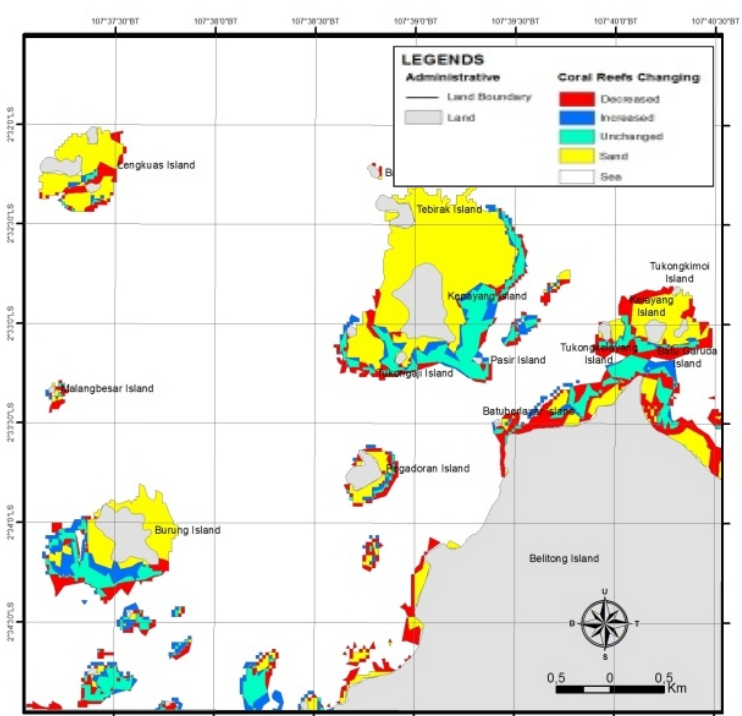

Fig. 5. Map of Coral Reefs Changing in 2011 and 2018.

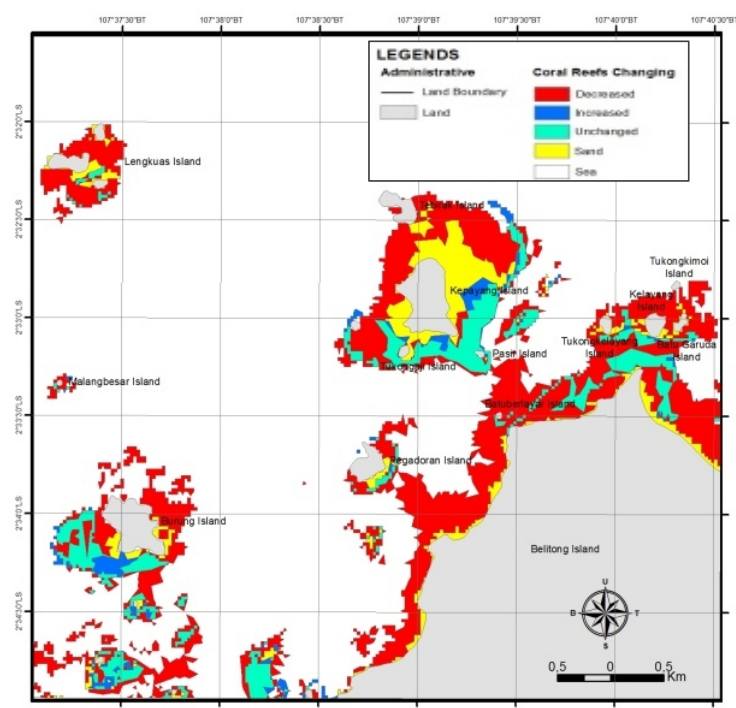

Fig. 6. Map of Coral Reefs Changing in 2005 and 2018.

Table 2. Coral Reefs Changing in Belitung in 2005-2018.

\begin{tabular}{|c|c|c|c|c|}
\hline \multirow{2}{*}{ No. } & \multirow{2}{*}{ Category } & $2005-2011$ & $2011-2018$ & $2005-2018$ \\
\cline { 3 - 5 } & & Area $\left(\mathrm{Km}^{2}\right)$ & Area $\left(\mathrm{Km}^{2}\right)$ & Area $\left(\mathrm{Km}^{2}\right)$ \\
\hline 1 & Unchanged & 1.45 & 0.90 & 1.12 \\
\hline 2 & Increased & 0.33 & 0.49 & 0.27 \\
\hline 3 & Decreased & 3.60 & 1.08 & 3.93 \\
\hline
\end{tabular}

Sources: Data Processing and Analysis

\subsection{Tourists in Belitung Tourism Destination Islands}

Based on the interviews with 30 tourists and 20 fishers who accompanied tourists, there are several snorkeling spots, there are two main snorkeling spots in Lengkuas Island in the east and west side of the island. Also, there is another spot in the south of Kepayang Island. With the interview with 30 tourists, $40 \%$ of tourists or 12 people know that fish feeding can cause loss of coral reefs. Then, $90 \%$ tourists or about 27 people know to step on the coral reefs can cause loss of coral reefs. Moreover, $97 \%$ of travelers or 29 people know that littering in the sea can cause loss of coral reefs.

\subsection{Tourists Boat in Belitung Tourism Destination Islands}

Based on the results of interviews that the researcher did with fishers, there are a few choices of a cruise line that boats always pass as shown in Figure 7. The line is heading from Tanjung Kelayang to Batu Garuda Island, Pasir Island, Batu Berlayar Island, Burung Island, Lengkuas Island, Kepayang Island, and Kelayang Island. With the main tourist activity is to do snorkeling on Lengkuas Island and Kepayang Island. In an interview with 20 fishers, $80 \%$ of fishers or 16 people knowing that the boats they used have an impact on coral reefs. Then, $30 \%$ of fishers or about six people have hit coral reefs with 
their boat, and about $35 \%$ or about seven people have put the anchor on the coral reefs in the island of a tourist destination. Furthermore, $45 \%$ of fishers or about nine people ever spilled fuel into the sea.

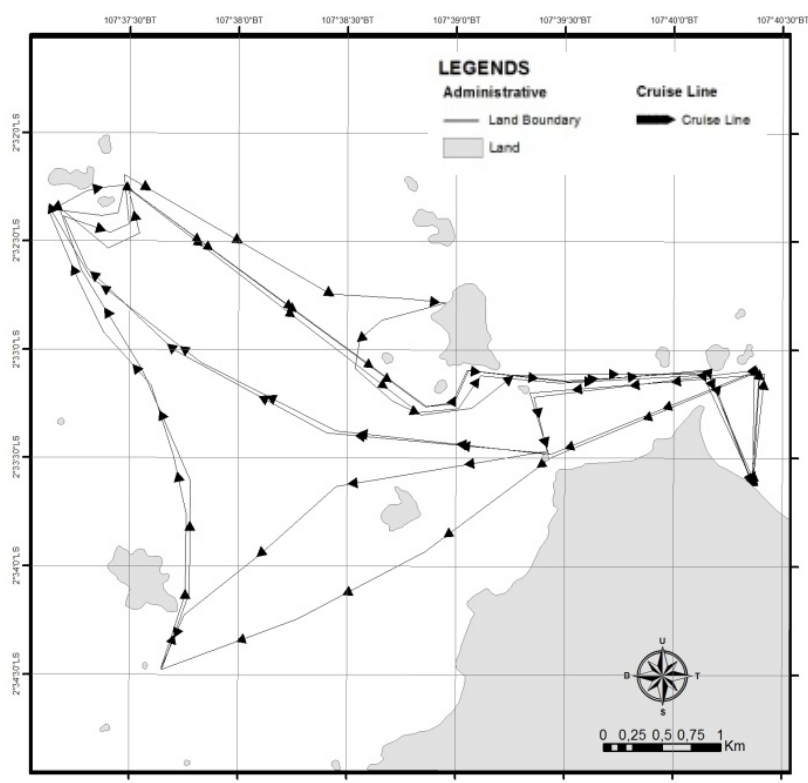

Fig. 7. Map of Cruise Line in Belitung Tourism Destination.

\subsection{Field Survey}

The verification has been done in the field to prove that the coral reefs in Figure 3 have the same condition in the field. If the coral reefs in Figure 3 are in good condition, then they will be in good condition or unchanged or increase in Figure 6. Though, if the coral reefs are in damaged condition, then it will be in damaged condition or decreased in Figure 6. For more, the condition of the coral reefs in the field can see in Figure 8, Figure 9, Figure 10, and Figure 11.

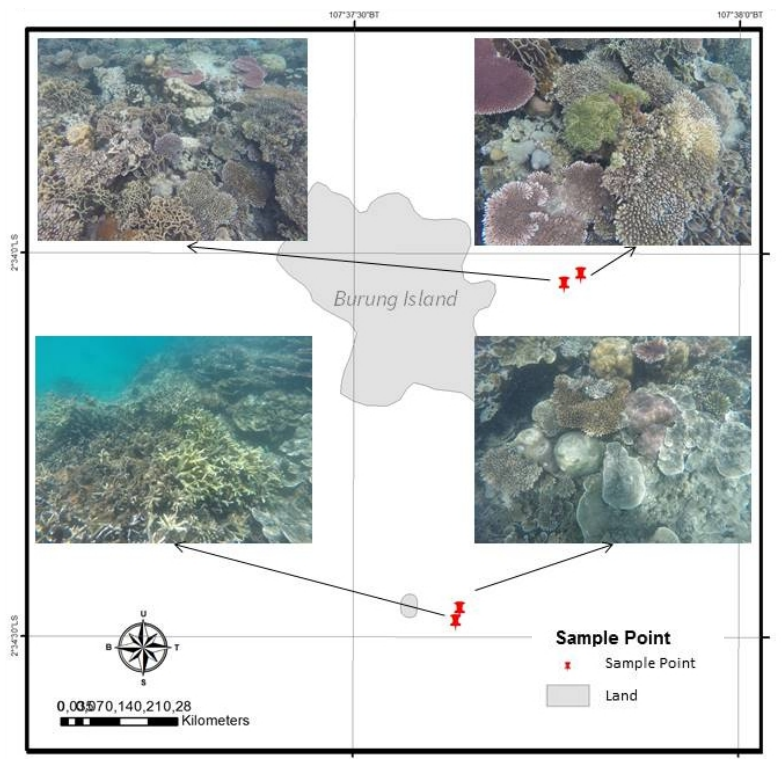

Fig. 8. Map of Sample Point in Burung Island.

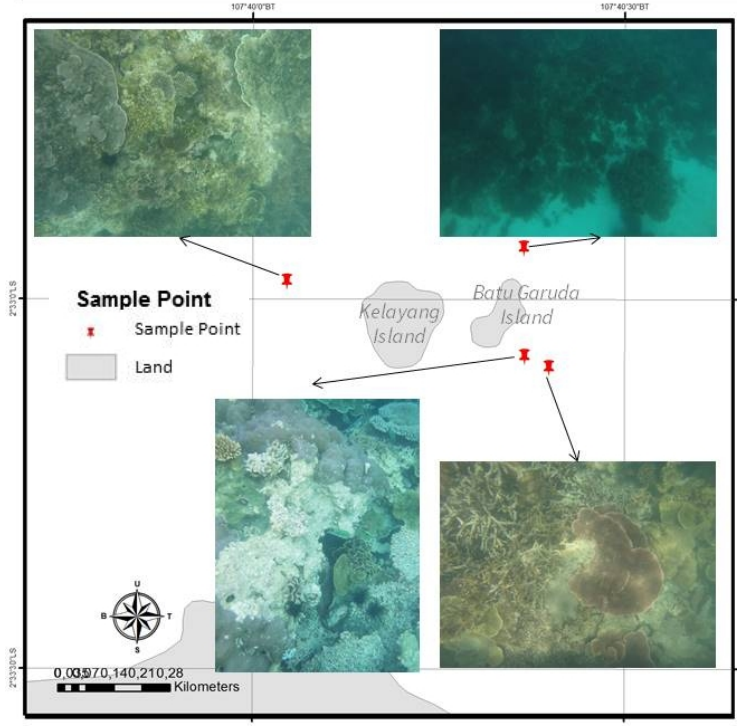

Fig. 9. Map of Sample Point in Kelayang and Batu Garuda Island.

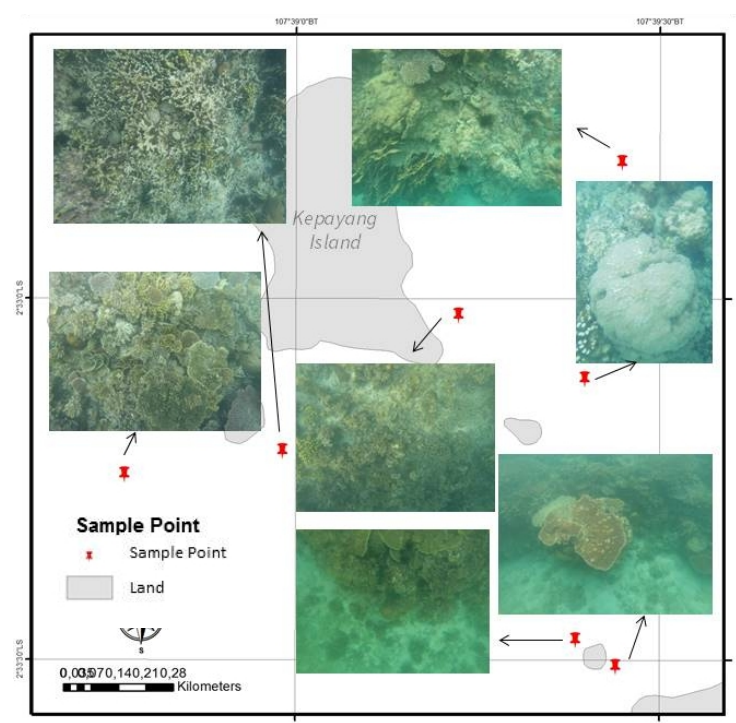

Fig. 10. Map of Sample Point in Kepayang Island.

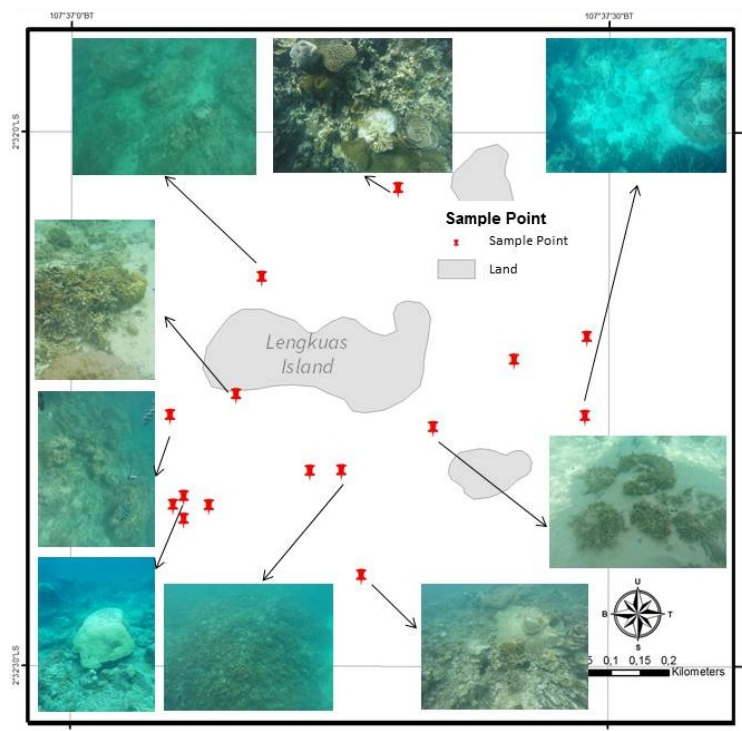

Fig. 11. Map of Sample Point in Lengkuas Island. 


\subsection{The Changing of Coral Reefs and its Factors in Belitung Tourism Destination Islands}

The correlation of the change in coral reefs area and its factor can see from the results of comparing the decreased area of coral reefs and the total area of coral reefs. The coral reefs area is divided into a grid of $120 \mathrm{x}$ 120 meters. Based on the results of the grid analysis in Figure 12, it inferred that in the main island of a tourist destination, such as Lengkuas Island, there are 14 grids of the decreased coral reefs are caused by a non-natural factor. In Kepayang Island, there are 16 grids. In Batu Berlayar Island, there are 18 grids. In Batu Garuda Island, there are 14 grids, Burung Island with 11 grids, Pegadoran Island as much as seven grids, and 13 grids around Tanjung Kelayang. With a total of 93 grids of the decreased area occurred by a non-natural factor, there is a total decreased area of $1.34 \mathrm{~km}^{2}$ or about $34.04 \%$ of the total damage that occurred caused by non-natural factors. That means $65.96 \%$ damage, caused by natural factors. It can be concluded that the decreased of the coral reefs occurred in Belitung tourism destination islands, are still dominated by natural factors rather than a non-natural factor.

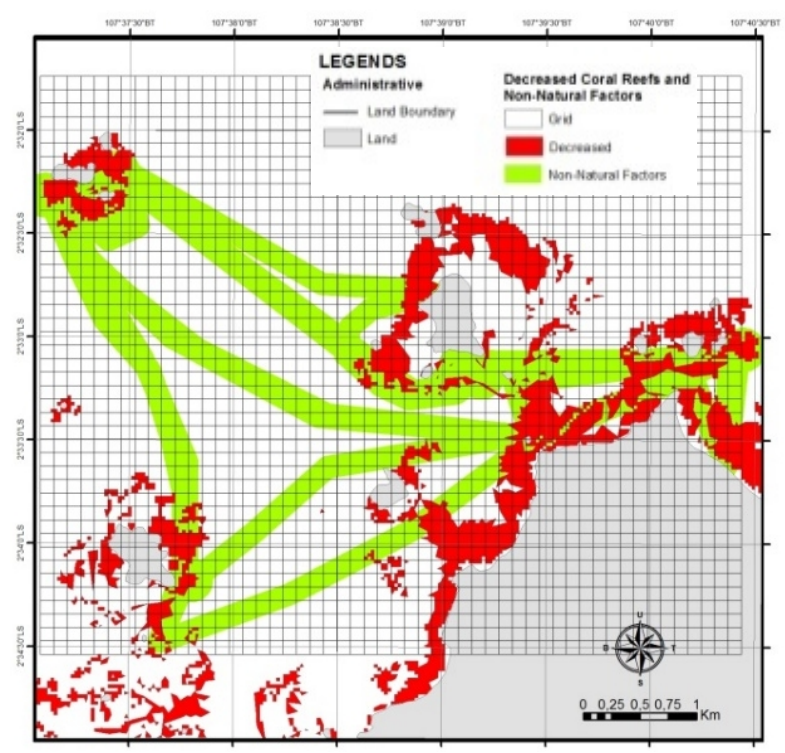

Fig. 12. Map of Decreased Coral Reefs Area and its NonNatural Factors in Belitung Tourism Destination.

\section{Conclusion}

Based on the results of the discussion, coral reefs have various percentages. In 2005, the area of coral reefs was up to $5.05 \mathrm{~km}^{2}$. In 2011, the area of coral reefs was 1.98 $\mathrm{km}^{2}$. Later in the year 2018, coral reefs have an area of
$1.39 \mathrm{~km}^{2}$. In 2005-2018, the total decreased area of the coral reefs occurs as much as $3.93 \mathrm{~km}^{2}$, the increased area of the coral reefs is $0.27 \mathrm{~km}^{2}$, and $1.12 \mathrm{~km}^{2}$ of coral reefs is unchanged. The decreased area of the coral reefs occurs in the north of Kepayang Island, southeast of Belitung Island, around Burung Island, around Batu Garuda Island and Kelayang Island, and around Lengkuas Island. Based on the results of the analysis of the changes of coral reefs area and its factor, it inferred that there are 93 grids or 1.34 $\mathrm{km}^{2}$ which have loss of coral reefs that caused by nonnatural factors, or about $34.04 \%$ of the total damage that occurs. That means $65.96 \%$ damage, caused by a natural factor. From the results of this analysis, it concluded that the decreased of the coral reefs occur in Belitung tourism destination islands, are still dominated by natural factors rather than a non-natural factor. The research findings can support the efforts that can be done by government and the tourism community, such as regulating tourism activities, including snorkeling in coral reef areas, and efforts to replant coral reefs or using eco-friendly boats to realize low carbon development.

The author would like to thank Directorate of Research and Community Service (DRPM) Universitas Indonesia, which has supported this research in HIBAH PITTA UI Year 2018 with contact number 2299/UN2.R3.1/HKP.05.00/2018.

\section{References}

[1] J. P. Gattuso, O. Hoegh-Guldberg, H. O. Portner, Cross-chapter box on coral reefs In Climate Change 2014: Impacts, Adaptation, and Vulnerability, 97100 (Cambridge University Press: Cambridge United Kingdom and New York NY USA, 2014)

[2] Asian Development Bank, State Of The Coral Triangle: Indonesia (Mandaluyong City, 2014)

[3] Bakosurtanal, Terumbu Karang Indonesia (Pusat Survei Sumberdaya Alam Laut Bakosurtanal, 2009)

[4] C. Wilkinson. (ed.), Status of Coral Reefs of the World: 2008 (Townsville, Global Coral Reef Monitoring Network and Reef and Rainforest Research Centre, 2008)

[5] World Meteorological Organization, Climate, Carbon, and Coral Reefs (Switzerland: World Meteorological Organization, 2010)

[6] M. D. M. Manessa, M. Haidar, S. Budhiman, G. Winarso, A. Kanno, T. Sagawa, M. Sekine, Evaluating the Performance of Lyzenga's Water Column Correction in Case-1 Coral Reef Water Using a Simulated Worldview-2 Imagery (IOP Conf. Ser.: Earth Environ. Sci, 2016) 